\title{
Organization Culture as an Explanation for Employee Discipline Practices
}

\author{
AIMEE L. FRANKLIN \\ University of Oklahoma \\ JAVIER F. PAGAN \\ University of Puerto Rico
}

\begin{abstract}
Most supervisors dread employee discipline and often employ strategies not officially sanctioned by the organization. Poorly designed discipline systems cause this variation in discipline practices. Inconsistent discipline can cause losses in productivity and reduce employee morale. Extant literature offers little in the form of guidance for improving this important human resource activity. This article explore where normative literature on organizational culture may have explanatory value for understanding variation in discipline practices. The article suggests two groups of factors that have causal effects on discipline practices. The tangible factors are those describing the formal practices the organization wishes its employees to follow. The intangible factors provide cues for explaining why informal strategies emerge as successful practices for getting things done. Using this conception of organization culture, the article proposes hypotheses for future testing to validate the suspected influence of culture on decisions regarding employee discipline.
\end{abstract}

Keywords: employee discipline; organizational culture; public human resources

C very day, first-line supervisors face the challenge of deciding what action Cto take when faced with employee performance problems. A common supervisory complaint is about employees who waste and misuse time. When employees persistently extend the time they take for coffee and lunch breaks, for example, by spending more than 25 to 30 minutes on each of the two 10minute coffee breaks in the day, productivity suffers. One supervisor may document the problems, counsel the employee, and note the action taken in the employee's personnel folder; another supervisor may choose to look the other way and take no action.

Why do supervisors use different strategies in some cases and avoid formal disciplinary action in others? The most frequently cited reason is the

Review of Public Personnel Administration, Vol. 26, No. 1 March 2006 52-73

DOI: $10.1177 / 0734371$ X05277335

(C) 2006 Sage Publications

52 
amount of time documentation requires (Ban, 1995). Other common explanations include a lack of managerial support evidenced by supervisory actions that are later overturned through the grievance and arbitration process. Consistent practices that follow organization policies avoid a loss of productivity associated with the administration of discipline, such as managerial time spent pursuing the steps in the discipline process, processing grievances, and hiring new employees. They also foster equity in employee treatment and prevent a demoralized workforce (Kearney \& Carnevale, 2001). Assuming that organizations value consistent disciplinary practices, discovery of factors causing supervisors to vary their discipline strategies is a valuable endeavor.

We suggest that explanations for variation in discipline practices can be discerned by exploring the influence of cultural cues supervisors receive regarding appropriate behavior. Recognized as a means for organization members to interpret and make sense of the work environment, symbols such as language, metaphors, objects, and rituals can influence employee actions (Goffman, 1967; Morgan, Frost, \& Pondy, 1983). The literature abounds with descriptions of behavioral cues found in an organization's culture. Schein (1992) used the term artifacts to describe the visible organization structures and processes that influence employee behavior. Hofstede (2001) described the symbols of an organization, for example, words, gestures, pictures, or objects, that carry a particular meaning. Cultural cues can also be characterized as stories and folklore surrounding watershed events that reinforce a code of conduct (Ingersoll \& Adams, 1992; Organ, 1987); symbols such as uniforms, workspaces, and building architecture (Goodsell, 1984; Pagan, 1998); or language, jargon, and rituals that differentiate members of different workgroups and organizations (Kunda, 1992; Martin, Hatch, \& Sitkin, 1983; Turner, 1971). Khademian (2002) labeled patterns of communication and language, rules of thumb, reference points for decision making, shared symbols, and stories as commitments associated with an organization.

Culture inside an organization defines the boundaries of acceptable action. It signals what work should be done and how that work is to be carried out (Kaufman, 1960). In terms of employee discipline, then, an organization's culture could define what a supervisor should consider as a problem that must be addressed. It could also prescribe what an acceptable response is, given that the supervisor faces a range of choices regarding what action to take.

To explore the relationship between employee discipline practices and organization culture, the first section of the article reviews the employee dis- 
cipline literature. The second section identifies tangible and intangible factors described in the organization culture literature that may have utility when considering variation in employee discipline. We organize these factors into two categories of cultural cues: those representing the official culture the organization wishes to foster and those reflecting pragmatic responses to disciplinary issues that have been developed by supervisors (in the third section of the article). Finally, we suggest hypotheses that can be tested to validate causal relationships between employee discipline strategies and variables representing the cultural cues supervisors receive.

\section{EMPLOYEE DISCIPLINE IN THE LITERATURE AND IN PRACTICE}

Every day first-line supervisors are confronted with employee behaviors that do not comply with the letter or the spirit of what the organization expects its employees to do and how that work is to be done. Employee infractions can range from innocuous behaviors such as failing to respond to a client inquiry quickly or being abrupt with a coworker to more egregious violations such as persistent insubordination, theft, or even sexual harassment. In this section, we define discipline and describe typical approaches to employee discipline. Then, we present the practical challenges supervisors experience when faced with discipline problems, and we review the formal and informal discipline strategies used by supervisors in response to these challenges.

Employee discipline has many definitions. Some focus on fostering productivity, others on ensuring compliance with policies or controlling behavior. Belohlav (1985) emphasized that making and keeping people productive is the function of the disciplinary process. Werther and Davis (1993) defined discipline as "management action to encourage compliance with organizational standards" (p. 548). Robbins (1994) argued that the term refers to "actions taken by a manager to enforce the organization's standards and regulations" (p. 544). Greer and Labig (1987) suggested that "[d]iscipline is an important, albeit distasteful function in almost every manager's job as he or she attempts to control undesired behavior in the work place" (p. 507).

Organizations typically have elaborate policies and procedures to guide the supervisor in responding to a wide range of employee performance problems. Two formal approaches to discipline systems are identified in the literature: the progressive sanctions approach and the positive approach. Many organizations have a formal disciplinary system featuring progressive 
sanctions, starting with verbal counseling and moving to written reprimands, suspension, and even termination. In some organizations, a positive discipline approach supplements the progressive approach with coaching and the development of supervisor-employee agreements to modify problem behavior. Under both systems, supervisors are encouraged to work with their managers and with their human resource departments (and union representatives, if applicable) to take the appropriate course of action in the correct sequence and to fully document the problem and the organizational response. In organizations with a union presence and collective bargaining agreements, uniform disciplinary practices are vital to ensure that supervisors handle cases consistently across time, increasing the likelihood that disciplinary actions will be upheld in grievance and, ultimately, arbitration actions (Klingner, 1980). An empirical study of public and private firms finds that organizations with a union presence do, in fact, have greater consistency. This is explained, in part, because the disciplinary system is made more transparent as supervisors carry a portable copy of the collective bargaining agreement. Furthermore, managers, human resource department personnel, and the union representative place high emphasis on abiding by the agreement (Pagan, 1998).

Supervisors may resist the assessment of subordinates and utilization of the discipline system, progressive or positive, given the difficulty of adequately expressing the performance contract and the desired results and job-related employee behavior (Nalbandian, 1981). When employee performance falls outside prescribed standards, supervisors may not feel comfortable substituting subjective judgments for formal evaluation tools. As described by Klingner and Nalbandian (2003), the psychological contract governing the relationship between employee and employer helps one to understand expectations and behaviors - tangible as well as intangiblethat occur when supervisors face discipline problems.

Of course, the supervisor has discretion in determining what constitutes a discipline problem requiring action and in choosing what course of action to take in response. Defining the behavior as a problem can be influenced by the employee's pedigree (e.g., a history of problem behavior). According to Bellizzi and Hasty (2000), "At times, however, similar or identical behaviors are met with different disciplinary actions and, in some cases, the cause of the differential action is tied to the personal characteristics of the subordinate" (p. 159).

In addition to variation in the definition of what a discipline problem is, there is also variation in the supervisor's response. Although disciplinary systems are supposed to guide discipline actions "because those policies are 
often quite nebulous, it is the managers within the organization" (Klaas \& Dell'Omo, 1991, p. 814) who seem to create or put into place strategies for dealing with disciplinary cases. Disciplinary actions taken in organizations vary greatly, and formal and informal methods, such as written warnings and off-the-record discussions between supervisors and subordinates, are widely employed (Greenberg \& Baron, 1995).

The use of sanctions and rewards may help to explain variation in disciplinary actions. There can be inadequate incentives or even disincentives that affect motivation to perform the work as expected (Argyris, 1964). Barnard (1938) described sanctions and rewards as basic factors in inducing individuals to work. Argyris (1964) argued that these will reinforce described activities and increase control over individual behavior. The rewards and penalties can be tangible and intangible. Those that relate directly to the work performed will be more robust (P. B. Clark \& Wilson, 1961). Organ (1987) documented the influence of cultural expectations when someone handles subordinates too harshly and is assigned to the penalty box-a meaningless job at the same level but in an undesirable location. Outsiders may view this as another job rotation; however, insiders know that the benched supervisor is temporarily "out of the game" (Organ, 1987, p. 473).

According to a U.S. Government Accountability Office (U.S. GAO; 1978) study, public organizations have similar informal tactics: Isolating, reassigning, long-term training, special assignments, early retirement offers, and promoting unsatisfactory employees are some examples of the informal methods of disciplining or getting rid of problem employees within some federal government agencies. Other research supports the findings that informal methods such as these are widely employed, in spite of the existence of formal rules and regulations for dealing with disciplinary issues (Ban, 1995; Beyer \& Trice, 1984; U.S. GAO, 1989, 1990; U.S. Merit Systems Protection Board [U.S. MSPB], 1992). Pagan and Franklin (2003) reported that $83 \%$ of supervisors interviewed in a public organization in Puerto Rico relied on informal rather than formal strategies when dealing with disciplinary issues.

This reliance on informal strategies is of concern because it suggests that formal systems are being circumvented; and, as a result, there is little consistency in the treatment of problem employees. Adhering to formal discipline policy is important because it ensures that supervisors are abiding by relevant laws and collective bargaining agreements (Kearney \& Carnevale, 2001). Such adherence can also be helpful in justifying disciplinary actions 
in grievance and arbitration processes. According to a study by Wheeler (1976), the vast majority of cases going through the grievance and appeal processes are related to disciplinary issues and problem employees. As Klingner (1980) pointed out, "Procedures are developed to . . . ensure equity of disciplinary and grievance actions by both parties" (pp. 390-391). Fostering equity in treatment can prevent a demoralized workforce and a resultant loss in productivity (Ban, 1995; Kaufman, 1960).

We suggest that the use of informal strategies can be better understood by examining the cultural cues that supervisors receive regarding how they should handle discipline problems. The role of culture in explaining variation in discipline practices has received some attention in the literature. Norms on discipline are shaped in practice by a whole range of informal practices, and supervisors may select informal approaches because their organization's culture supports them over formal approaches of dealing with employee discipline (Edwards \& Scullion, 1982; Gaertner \& Gaertner, 1984). Ban (1995) supported this statement when she pointed out that "managers learn by watching ... and seeing 'how things are done' in their organizations. Their decisions are also based ... on what is valued in their organizations" (pp. 69-70). We can conclude, then, that the choice of discipline strategies may be based on cultural cues suggesting that formal strategies are not really the way things are done in an organization. This possibility is explored in the next section.

\section{ORGANIZATION CULTURE LITERATURE}

Culture provides guidance on what an organization's employees can do and how they can do it. Argyris and Schon introduced the concept of espoused values in 1974 . They argued that an organization will prescribe desired behavior as what employees ought to do; however, actual practice will differ based on the situation, relevant assumptions, and intended outcomes, even though employees claim they behave according to corporateespoused values. These differences result in theories of action that determine the actual behavior of professional practitioners (Argyris \& Schon, 1974). Thus, there can be a disconnect between what the organization officially prescribes, what the employee accepts as reasonable behavior, and what the employee does. Explanation of what causes these differences among espoused values, theories of action, and theories in use, we argue, can be discerned through greater examination of organization culture. 
Schein (1992) also used the concept of espoused values to represent the midrange level of culture that consisted of justifications of strategies, goals, and philosophies of the organization.

One can discern culture in any organization by looking for tangible and intangible cues (Schein, 1992; Smircich, 1983). Tangible cues can be found in things such as the characteristics of the physical facilities; appearance of the employees and their workspaces; the structure of the organization; the formality and clarity of discipline manuals, rules, and processes; and the emphasis on management-related education and training. The intangible cues are more relationship based, as employees working in a group learn acceptable responses to problems they encounter (Schein, 1985). Intangible cues can be found by studying employee interactions, such as the dayto-day relationships supervisors have with their managers, other supervisors, employees, the human resource department, and union delegates.

Czarniawska-Joerges (1992) addressed the tangible and the intangible components of culture: "Culture is the actual ways of doing things as contrasted to those prescribed in documents, decisions, and regulations" (p. 174). Others focused on the tangible cues as well. Khademian (2002) suggested tangible cues describe how work should be done. Kunda (1992) defined culture as "rules for behavior, thought, and feeling, all adding up to what appears to be a well-defined and widely shared member role" (p. 7).

Extant literature that focuses more on the intangible component often defines culture in terms of group dynamics. Perhaps one of the most frequently cited definitions of the concept has been offered by Edgar Schein. In his perspective, culture is seen as the "basic assumptions and beliefs that are shared by members of an organization, that operate unconsciously, and that define in a basic 'taken for granted' fashion an organization's view of itself and its environment" (Schein, 1985, p. 6). Imundo (1985) suggested that "[culture] is most readily observed by the ways employees behave in their roles" (p. 21). Along this line, Kilman, Saxton, and Serpa (1986) defined the concept as

the shared philosophies, ideologies, values, assumptions, beliefs, expectations, attitudes, and norms that knit a community together. All of these interrelated psychological qualities reveal a group's agreement, implicit or explicit, on how to approach decisions and problems. (p. 89)

For Barley (1983), culture within organizations "is best understood as a set of assumptions or an interpretative framework that undergirds daily life in an organization or occupation." (p. 399) 
There is little consensus regarding the definition of culture (Frost, Moore, Louis, Lundberg, \& Martin, 1985; Ingersoll \& Adams, 1992; Martin, 2002). Literature on organizational sociology suggests culture is a combination of formal and informal norms that create a psychological contract between employees and employers (Nalbandian, 1981). Others have characterized it as the personification of national culture (Hofstede, 2001; Ingersoll \& Adams, 1992). Another line of literature restricts culture to that found within organizations. Through meta-analysis, Martin (1992) developed three organizing perspectives for cultural studies, attributing differences in conceptual definition to different units of analysis, orientation, and interpretation of subjectively examined empirical facts.

For this article, we operationalized culture as a system of shared values and beliefs constructed by an organization and by its employees through tangible and intangible cues. These values and beliefs serve as the general guides through which the organization directs its members' behaviors to be able to solve their problems and work productively. Extant literature suggests several cultural factors that may have explanatory value in understanding variation in employee discipline. In this section, we review the literature on the tangible and intangible components of culture to determine where they may be applicable to the issue of employee discipline.

New employees learn culture after they enter the organization, and this learning process can continue indefinitely as the employee gains more experience and the organization's culture evolves over time (Louis, 1980; Seidman \& Gilmour, 1986; Wanous, 1980). Depending on the organization, the induction process may be very timely and detailed, such as providing a new-employee orientation session and making reference documents (such as employee handbooks or the collective bargaining agreement) and discipline policies available and accessible. Alternatively, it may be just the opposite, with little or no effort expended by managers or human resource personnel to ease the new employee's entry into the organization (Pagan \& Franklin, 2003; Wanous, 1980). Instead, socialization may occur through subtle changes and adjustments as the new employee becomes an accepted member of a work group (Adkins, 1995) and tests lessons in a socialization chain (Van Maanen, 1984).

The socialization, or acculturation, process helps people adapt to their new jobs as they learn the assumptions, beliefs, values, norms, and behaviors necessary to function effectively in the organization (Fisher, 1986; Ott, 1989; Schein, 1968; Van Maanen, 1976). This introduction signals how the organization expects supervisors to handle employee infractions. In terms of employee discipline, ensuring consistency in supervisors' actions 
can depend, largely, on the resources committed to a systematic acculturation process. Thus, we expect that variation in employee discipline will decrease when the organization offers a timely, detailed orientation and makes important documents outlining the discipline process available.

Written documents play a very important role in setting expectations regarding discipline practices in an organization. As described previously, each organization will have detailed policies and procedures outlining the steps of the discipline process. In addition to the organization's specific policies, the supervisor must also follow formal civil service regulations and collective bargaining agreements when taking disciplinary actions. These documents often complicate the disciplinary process in the public sector (Ban, 1995; Ban, Goldenberg, \& Marzotto, 1982; Ban \& Riccucci, 1991; Shafritz, Riccucci, Rosenbloom, \& Hyde, 1992). For example, collective bargaining agreements usually prescribe in detail the actions for which supervisors may subject employees to disciplinary actions and terminations (Freeman \& Medoff, 1984; Katz \& Kochan, 1992; Rosenbloom \& Shafritz, 1985). As Rivas (1991) put it "[T]he organization of the work force and the presence of labor unions tend to require managers to exercise due process in disciplinary actions" (p. 191). When policies are clear, understood, and accepted as valid, supervisors are more likely to follow formal disciplinary policies (Pagan \& Franklin, 2003). Of course, the supervisor may utilize formal discipline practices because higher management has signaled, through the allocation of resources and time, that it supports formal actions and will sanction those who do not conform. Therefore, we expect written documents to influence supervisors' approaches to employee discipline, especially when upper-level management reinforces these actions.

It has been recognized that a systematic and formal transmission of organizational disciplinary standards is important for effective operations (Imundo, 1985). Training is one way to accomplish this objective. However, research shows that supervisors within their respective organizations rarely receive training in supervisory skills (Klingner, 1980). Moreover, when supervisors receive training, it appears to be highly superficial in nature and does not teach them how to handle the difficulties usually associated with disciplinary cases (Bryant, 1984). Studies conducted by Ban (1995) indicate that a "dearth of adequate training means that many people have to learn how to manage informally, on the job" and "never really get a firm grasp on the complex personnel system" (pp. 60-61). Inadequately trained supervisors have considerably more problems in dealing with poor performers (Robisch, 1996). Therefore, another tangible aspect of organi- 
zation culture that may influence disciplinary practices is the organization's commitment to training on formal discipline policies.

The structure of the organization may also influence employee discipline practices. When looking at structure, things such as the lines of authority and span of control must be considered. Authority may be limited during a probationary period as superiors judge the qualifications of the employee (Kaufman, 1960). As another example of how organizational and environmental factors can influence supervisors' performances, many federal organizations do not delegate much authority to first-line supervisors to make decisions and take actions. This leaves "supervisors out in the trenches with little authority to do the things that they deem necessary for the effective and efficient operation of the work unit" (U.S. MSPB, 1992, p. 27). Many first-line supervisors feel that the real authority, particularly on a matter as controversial as discipline, lies above them-sometimes several levels above them (Ban, 1995). Unfortunately, although first-line supervisors are responsible for conducting many of the activities related to employee discipline and problem employees, they are sometimes denied authority over them (U.S. Navy Personnel Research and Development Center, 1984).

The number of employees that a supervisor oversees is another structural issue that affects discipline practices. Supervisors who frequently use formal warnings as a method of correcting problem employees are usually those who have more subordinates under their direct supervision (Podsakoff, 1982). In this sense, as the span of control increases, supervisors may be more inclined to fire problem employees than to counsel them. Therefore, first-line supervisors' handling of employee discipline can also be affected by unclear delegation of authority or variation in the span of control.

Over time, empirical studies have found that culture is heavily dependent on history or the actions of a specific individual and/or leader (Barnard, 1938; Kaufman, 1960; Kunda, 1992; Riccucci, 1995; Schein, 1992). Thus, the people inside the organization can provide intangible cues about expected employee behaviors. There are four types of individuals or groups that can influence the supervisor's choice of disciplinary actions: organization management (including the HR department), the problem employee, the supervisor's peers, and groups providing overlapping value systems. Normative prescriptions for each of these as they relate to employee discipline are considered next.

In a GAO (U.S. GAO, 1978) report, it was found that "supervisors and managers perceive firing as a difficult chore which often lacks top-level management support" (p. ii). Managers "are likely to go through the lengthy and complex formal process only if they have strong support from 
their superiors (sometimes several layers up) and from the employee relations staff" (Ban, 1995, p. 81). Decisions made by supervisors are often overruled by higher levels of management or by staff specialists (Imundo, 1985, pp. 5-6). Campbell, Flemming, and Grote (1985) argued that "not only do they catch flak from below but supervisors also discover that maintaining discipline may produce reversed decisions 'upstairs" (p. 168). Such a situation leads to a condition where "supervisors and employees perceive their agencies as non supportive should they want to fire someone" (U.S. GAO, 1978, p. 17). From this, we can conclude that when considering the relationship between the supervisor and organization management, if there is a sense of support, it is more likely that supervisors will pursue formal disciplinary actions. If supervisors fear their decisions will not be supported and will perhaps be overruled, the use of informal strategies is more likely.

The relationship between the supervisor and the subordinate may also affect the choice of discipline strategies. Research conducted by Rosen and Jerdee (1974) found that offenders' (subordinates') characteristics, such as status and talent, appear to influence supervisors' judgments and application of disciplinary sanctions. Participants in this study tended to be more lenient in applying sanctions, for the same rule violation, if positive characteristics were present. The approach supervisors take to someone with inadequate skills can differ from that taken to an employee with personal problems (Ban, 1995). Based on these observations, it is likely that formal strategies will be favored when the employee has unsatisfactory personal skills.

The norms of referent, or reference, groups can be highly influential in shaping employee behaviors. A referent group is a group whose values, norms, and perspectives guide the employee's behavior in social situations (R. E. Clark, 1972). In 1957, Merton suggested that a person compares herself or himself with others in the same situation when deciding how to interpret an experience. Others argued that role models are necessary to have adequate role performance (Ingersoll \& Adams, 1992; Kemper, 1968). This is part of the identification process through which people respond to social influence. When identification occurs, compliance and internalization serve to align group member behavior (Kelman, 1961). Bion (1961) reinforced this notion in his finding that there are "basic assumptions" or dynamics that operate within groups and guide member behavior and reactions to other members. Failure to conform can lead to sanctions or removal (R. E. Clark, 1972). 
Studies of faculty members by Gouldner (1957, 1958; later replicated by Flango \& Brumbaugh, 1974) examined the influence of manifest and latent social roles on organization loyalty, commitment to professional skills and values, and reference group orientations. Two general types of organization members are identified in the university setting: cosmopolitans and locals. Locals use an inner reference group orientation and are highly identified with the current organization. They are so-called company men who seek to get along with others to make the organization succeed. Cosmopolitans are less concerned with the internal operations of their current organization and more concerned with establishing themselves as experts in, and gaining recognition from, the professional community at large. These findings suggest that referent groups occur inside and outside the organization's boundaries.

For supervisors, their peers, that is, other supervisors (inside and outside the organizations) and managers are the primary referent groups. As Klaas and Dell'Omo (1991) pointed out, although disciplinary systems are supposed to guide general behavior "because those policies are often quite nebulous, it is the managers within the organization" (p. 814) who seem to create or put into place adequate strategies and/or approaches to help them navigate through the complexities usually associated with disciplinary cases. Others comment that supervisors' individual and peer group norms are ingrained and/or programmed into each employee (Argyris, 1967) and passed on and/or transmitted from generation to generation (Harrison \& Carroll, 1991; Kaufman, 1960). Research by Podsakoff (1982) supports this assumption in the conclusion that "less experienced supervisors are more likely to refer their problems to someone else" (p. 73). If supervisors, as a group within an organization, tend to follow formal discipline policy, we expect to find that individual supervisors will be more likely to use formal approaches as well. The opposite, a prevalence of informal strategies will foster approaches that are more informal, is predicted as well.

Overlapping cultural influences on an individual, such as those held by professional, social and/or affiliation, religious, family, and societal groups, constitute additional referent groups that may influence disciplinary practices (Franklin \& Raadschelders, 2004; Hofstede, 2001; Van Maanen \& Barley, 1984). Existing empirical literature does not test the influence of these external referent groups in the discipline process. The literature on culture, however, does suggest that the norms, values, and beliefs of an organization need to closely align with an individual's preexisting beliefs to be 
self-enforcing (Argyris, 1989; Blau \& Scott, 1962). If there are conflicts in value systems, then there may be differences in employees' perceptions of expected behavior (French \& Bell, 1999; Martin, 1992). As a result, disciplinary actions may vary because employees will resist values that are dissonant with those they hold outside work (Deal \& Kennedy, 1982; Juran, 1964). Therefore, we can infer that the choice of discipline strategies can also be influenced by the values the supervisor holds that are reinforced by individuals and groups outside the workplace.

In reviewing the literature, it appears that several tangible and intangible cultural factors representing the formal or officially sanctioned behaviors, and the informal or unofficially developed norms, respectively, may influence the choice of discipline strategies. Assuming that it is desirable for all supervisors to be consistent in the employee discipline process and that formal strategies are favored for productivity, equity, and morale reasons, we offer these hypotheses regarding the influence of culture on employee discipline.

\section{Tangible Factors (Formal or Officially Sanctioned)}

- Socialization and/or acculturation experience: If the organization provides an orientation that is timely and detailed, the supervisor will be more likely to use the formal discipline process.

- Written documents: If the relevant policies and procedures are given to the supervisor and are useful, the supervisor will be more likely to use the formal discipline process.

- Training: If the organization provides training on discipline, the supervisor will be more likely to use the formal discipline process.

- Organization structure: If the organization vests authority with the supervisor and if the supervisor has a larger span of control, the supervisor will be more likely to use the formal discipline process.

\section{Intangible Factors: (Informal or Unofficially Developed)}

- Problem employees: If the employee does not have good job skills or high status, the supervisor will be more likely to use the formal discipline process.

- Socialization/acculturation occurring through referent group HR department): If supervisory decisions are supported and not overturned by organizational management, the supervisor will be more likely to use the formal discipline process.

- Peers: If other supervisors follow the formal discipline process, the supervisor will be more likely to use the formal discipline process. 
- Groups outside work: If overlapping value systems fostered by groups outside work reinforce the expectations supported by the organization's culture, the supervisor will be more likely to use the formal discipline process.

Although these tangible and intangible factors are thought to be important for explaining bivariate relationships, we suspect that there may also be interaction effects between the two types of cultural cues (tangible and intangible). We explore this possibility in the next section.

\section{ORGANIZATION CULTURE AS AN EXPLANATORY FACTOR}

From these observations regarding different cultural factors, we suggest that an organization's culture can be thought of as being composed of two distinct dimensions: one that constitutes the official culture of what we do and how we do it, and the operating culture of how work is really done. Supervisors can rely on stated and unstated assumptions of what constitutes appropriate behavior. One is overt and explicit, and the other is tacit and implicit (Gibson, Ivancevich, \& Donnelly, 2000; Ingersoll \& Adams, 1992). The organization attempts to prescribe formally what employees are expected to do and how they are expected to do it through the tangible factors. We label this the official culture and propose that it is signaled through tangible cues as the organization attempts to guide (and regulate) supervisors' actions. The intangible factors, as a group, are given the label operating culture because they prescribe allowable behaviors for how work really is done. These behaviors are negotiated through interpersonal interactions as employees, working in a group, learn successful responses to resolving problems (Argyris \& Schon, 1974; Schein, 1992). The operating culture provides cues suggesting the rules of thumb for acceptable behavior given different problems. It defines how things are really done and outlines where there is flexibility in following official standards. In this section, we suggest that the two types of factors influencing culture, tangible and intangible, provide important cues as the supervisor searches the official and operating dimensions of culture for information regarding appropriate behavior.

We can combine the cues a supervisor receives regarding the two dimensions of culture, official standards and operating guidance, in three ways: (a) providing the same prescription for action, (b) providing similar prescriptions with slight inconsistencies, or (c) providing different prescriptions. Expectations regarding these combinations are described below; however, these are untested hypotheses that warrant empirical testing. One might 
Table 1. Managing the Official and Operating Dimensions of Cultures

\begin{tabular}{|c|c|c|c|}
\hline & $\begin{array}{c}\text { Operating } \\
\text { Guidance (Based on } \\
\text { Intangible Cues) }\end{array}$ & $\begin{array}{l}\text { Supervisor } \\
\text { Experiences }\end{array}$ & $\begin{array}{c}\text { Disciplinary Strategies } \\
\text { Used by Supervisors }\end{array}$ \\
\hline \multirow[t]{3}{*}{$\begin{array}{l}\text { Official standards } \\
\text { (based on tangible cues) }\end{array}$} & Same & No dissonance & $\begin{array}{l}\text { Consistent, formal } \\
\text { strategies }\end{array}$ \\
\hline & Similar & Discretion & $\begin{array}{c}\text { Unpredictable, mixed } \\
\text { strategies, but bias } \\
\text { toward formal }\end{array}$ \\
\hline & Different & Dissonance & $\begin{array}{c}\text { Inconsistent, informal } \\
\text { strategies dominant }\end{array}$ \\
\hline
\end{tabular}

assume that based on these three conditions, the supervisor experiences different levels of congruence or dissonance (Argyris \& Schon, 1974), and that may explain variation in the use of formal or informal discipline strategies. Cognitive dissonance (Argyris, 1989) occurs when there are discrepancies between the official statements describing expectations for employee actions and normal employee behaviors. In terms of discipline systems, the optimal situation is the alignment and integration of the tangible cultural cues received from official standards with the intangible cues received in the form of operating guidance from others in the organization. This framework, presented in Table 1, provides a starting point for the development of hypotheses that can be tested empirically as the next stage of theory development.

In the first combination, there is no dissonance in the cues received from the official and operating cultures regarding what disciplinary actions are expected. In this case, it is likely that formal strategies will be used because the tangible and intangible cues suggest that policies and procedures should be followed. In addition, there is a greater likelihood that there will be consistency between supervisors, with a tendency to favor formal strategies that are clearly described in written documents and reinforced in orientation and training events.

When the two dimensions provide similar cues, the supervisor is now faced with a choice of following the formal policy stated in the official standards or choosing other strategies learned through interactions with other groups. In this situation, the choice of discipline strategies is unpredictable; however, it may be reasonable to expect that the supervisor will follow official policy and try a formal strategy to avoid jeopardizing his or her job. The 
effectiveness of cultural cues to guide behavior decreases when the messages between the official and operating dimensions are inconsistent because the employee has to determine what factors (cues) are assigned greater weight relative to the others and decipher which signals are correct in the view of a majority of members in most situations. In short, the problem is that intangible cues are more subjective and lead to greater variations in perceptions and interpretations.

In the third combination, the cues received regarding official standards and operating guidance are in conflict. When this occurs, the supervisor experiences dissonance. The discrepancy between what is expected and what is actually being done will be evaluated by the supervisor to determine how important the difference is and if there is a strategy that will accommodate both sets of cues. However, we hypothesize that in this situation, supervisors will favor informal strategies that ignore the problem, hoping it will go away; or they will take steps proactively to make the problem go away. Recall that common informal strategies are ignoring, isolating, reassigning, transferring, offering early retirement, and promoting unsatisfactory employees. None of these takes a great deal of effort from the supervisor. On the other hand, formal strategies are described as time-consuming and seldom successful. Thus, we speculate that the supervisor's bias will be toward the self-interested behavior supported by informal strategies. In addition, because supervisors learn informal strategies through interactions, and not all supervisors interact with all other supervisors and managers, the highest level of variation in discipline practices is expected.

\section{DISCUSSION}

In this article, we suggest two dimensions of culture that provide cues to employees regarding acceptable behavior. In elaborating these dimensions, we do not seek to provide the ultimate definition of culture; rather, we attempt to provide a framework for empirical confirmation and theory extension. Using the two dimensions of culture, official and operating, to analyze how supervisors choose between formal and informal strategies can be useful for decreasing variation in employee discipline practices. It can be assumed that official organizational efforts designed to make desired employee discipline practices transparent to supervisors can increase the likelihood that formal, rather than informal, disciplinary strategies prevail.

To improve the consistency between the official standards and the operating guidance dimensions and to reduce variation in employee discipline 
practices, organizations can identify the cues employees receive (Sackmann, 1991) regarding both dimensions of culture. For situations where the cues are contradictory or inconsistent, this line of inquiry can be informative for identifying what types of targeted interventions (Detert, Schroeder, \& Mauriel, 2000) may have utility in terms of encouraging a unified and consistent approach to discipline. If it is observed that the official culture is sending inconsistent signals, then actions such as rewriting the discipline manual to make it more user friendly or offering training focusing on disciplinary processes will be beneficial.

Attempts to modify an inconsistent operating culture may include teambuilding or communication exercises (although it is acknowledged that changes of this nature are more difficult to attain and can take a long time; see Selznick, 1948). Changes to the official standards can focus on institutional structure and/or mechanisms and can be based in traditional or authority-based leadership and are forcible in the short term (Senge, 1990). Changes to the operating guidelines require that acceptance be gained through charismatic leadership, dialogue, and negotiation with the organization's members (Selznick, 1948; Van Blijswijk, Van Breukelen, Franklin, Raadschelders, \& Slump, 2004); and as Carnevale (2003) pointed out, this may take longer than other actions to change organization culture.

The definition of culture as being composed of two dimensions representing the official standards (as described in tangible cues) and operating guidance (as learned through intangible cues) can be useful in assessing why supervisors prefer certain disciplinary strategies. Of course, implying a strict demarcation between tangible and intangible cues is false; the categories are not mutually exclusive. However, it does serve to illustrate the difference between the official and the operating dimensions of culture. The hypotheses predicting bivariate relationships between each of the cultural factors in the tangible and intangible groups need deductive validation. Then, research can be undertaken to test the predictive validity of the model presented in Table 1, suggesting interaction effects between the factors representing the two dimensions of an organization's culture. Future studies should test these causal relationships across a large-scale, representative sample of organizations.

\section{CONCLUSION}

Organizations struggle to create employee discipline systems that are used by their supervisors. When supervisors follow formal policies, produc- 
tivity is enhanced and equity is preserved. However, empirical evidence suggests that informal strategies are common when supervisors confront discipline problems. Using extant literature, we suggest that there are cultural factors that can explain why there is variation in the selection of discipline strategies. These factors are grouped into two categories, tangible and intangible cues, describing what are expected and what are acceptable behaviors, respectively. The tangible cues represent the official expectations of the organization. These cues are present in the employee induction process, written documents, training events, and the structure of the organization. The intangible cues give guidance on what is really done in daily operations. Relationships and interactions with organization management, other supervisors, problem employees, and other referent groups outside of work are the source of intangible cues for acceptable behaviors. We argue that these two dimensions interact in three combinations influencing the choice of discipline strategy and the likelihood that there will be consistency between supervisors. Without mutually reinforcing cues, the strategies supervisors use may not be in accord with organizational preferences and may vary widely, leading to unsatisfactory outcomes. Given the high levels of dissatisfaction that already exist with employee discipline practices, we suggest that the proposed influence of culture is one that deserves greater attention among public management scholars.

\section{REFERENCES}

Adkins, C. L. (1995). Previous work experience and organizational socialization: A longitudinal examination. Academy of Management Journal, 38(3), 839-862.

Argyris, C. (1964). Integrating the individual and the organization. New York: John Wiley.

Argyris, C. (1967). Executive leadership: An appraisal of a manager in action. Hamden, CT: Archon.

Argyris, C. (1989). The individual and the organization. In W. E. Natemeyer \& J. S. Gilberg (Eds.), Classics of organizational behavior (2nd ed., pp. 21-35). Oak Park, IL: Moore.

Argyris, C., \& Schon, D. A. (1974). Theory in practice: Increasing professional effectiveness. San Francisco: Jossey-Bass.

Ban, C. (1995). How do public managers manage? Bureaucratic constraints, organizational culture, and the potential for reform. San Francisco: Jossey-Bass.

Ban, C., Goldenberg, E. N., \& Marzotto, T. (1982). Firing the unproductive employee: Will civil service reform make a difference? Review of Public Personnel Administration, 2(2), 87-100.

Ban, C., \& Riccucci, N. (1991). Public personnel management: Current concerns-future challenges. White Plains, NY: Longman.

Barley, S. R. (1983). Semiotics and the study of occupational and organizational cultures. Administrative Science Quarterly, 28(3), 393-413. 
Barnard, C. I. (1938). The functions of the executive. Cambridge, MA: Harvard University Press.

Bellizzi, J. A., \& Hasty, R. (2000). The effects of hiring decisions on the level of discipline used in response to poor performance. Management Decision, 38(3), 154-159.

Belohlav, J. A. (1985). The art of disciplining your employees: A manager's guide. Englewood Cliffs, NJ: Prentice Hall.

Beyer, J. M., \& Trice, H. M. (1984). A field study of the use and perceived effects of discipline in controlling work performance. Academy of Management Journal, 27(4), 743-764.

Bion, W. R. (1961). Experiences in groups. London: Tavistock.

Blau, P. M., \& Scott, W. R. (1962). Formal organizations: A comparative approach. San Francisco: Chandler.

Bryant, A. W. (1984). Replacing punitive discipline with a positive approach. Personnel Administrator, 29(2), 79-87.

Campbell, D. N., Flemming, R. L., \& Grote, R. C. (1985). Discipline without punishmentat last. Harvard Business Review, 63(4), 162-174.

Carnevale, D. G. (2003). Organizational development in the public sector. Boulder, CO: Westview.

Clark, P. B., \& Wilson, J. Q. (1961). Incentive systems: A theory of organizations. Administrative Science Quarterly, 6(2), 134-135.

Clark, R. E. (1972). Reference group theory and delinquency. New York: Behavioral Publications.

Czarniawska-Joerges, B. (1992). Exploring complex organizations: A cultural perspective. Newbury Park, CA: Sage.

Deal, T. E., \& Kennedy, A. A. (1982). Corporate cultures: The rites and rituals of corporate life. Reading, MA: Addison-Wesley.

Detert, J. R., Schroeder, R. G., \& Mauriel, J. J. (2000). A framework for linking culture and improvement initiatives in organizations. Academy of Management Review, 25(4), 850872.

Edwards, P. K., \& Scullion, H. (1982). Deviancy theory and industrial praxis: A study of discipline and social control in an industrial setting. Sociology, 16(3), 322-340.

Fisher, C. D. (1986). Organizational socialization: An integrative review. Research in Personnel and Human Resources Management, 4, 101-145.

Flango, V. E., \& Brumbaugh, R. B. (1974). The dimensionality of the cosmopolitan-local construct. Administrative Science Quarterly, 19(2), 198-210.

Franklin, A. L., \& Raadschelders, J. C. N. (2004). Ethics in local government budgetingIs there a gap between theory and practice? Public Administration Quarterly, 27(4), 456490.

Freeman, R. B., \& Medoff, J. L. (1984). What do unions do? New York: Basic Books.

French, W. L., \& Bell, C. (1999). Organization development: Behavioral science interventions for organizational improvement (6th ed.). Upper Saddle River, NJ: Prentice Hall.

Frost, P. J., Moore, L., Louis, M., Lundberg, C., \& Martin, J. (Eds.). (1985). Organizational culture. Beverly Hills, CA: Sage.

Gaertner, G. H., \& Gaertner, K. N. (1984). Formal disciplinary actions in two federal agencies. Review of Public Personnel Administration, 5(1), 12-24.

Gibson, J. L., Ivancevich, J. M., \& Donnelly, J. H. (2000). Organization: Behavior, structure, processes. Boston: Irwin, McGraw-Hill.

Goffman, E. (1967). Interaction ritual. New York: Anchor. 
Goodsell, C. T. (1984). Welfare waiting rooms. Urban Life, 12, 467-477.

Gouldner, A. W. (1957). Cosmopolitans and locals: Toward an analysis of latent social roles -I. Administrative Science Quarterly, 2(3), 281-306.

Gouldner, A. W. (1958). Cosmopolitans and locals: Toward an analysis of latent social roles -II. Administrative Science Quarterly, 2(4), 444-480.

Greenberg, J., \& Baron, R. A. (1995). Behavior in organizations (5th ed.). Englewood Cliffs, NJ: Prentice Hall.

Greer, C. R., \& Labig, C. E. (1987). Employee reactions to disciplinary actions. Human Relations, 40(8), 507-524.

Harrison, J. R., \& Carroll, G. R. (1991). Keeping the faith: A model of cultural transmission in formal organizations. Administrative Science Quarterly, 36(4), 552-582.

Hofstede, G. (2001). Culture's consequences: Comparing values, behaviors, institutions, and organizations across nations (2nd ed.). Thousand Oaks, CA: Sage.

Imundo, L. V. (1985). Employee discipline: How to do it right. Belmont, CA: Wadsworth. Ingersoll, V. H., \& Adams, G. B. (1992). The tacit organization. Greenwich, CT: JAI.

Juran, J. M. (1964). Managerial breakthrough: A new concept of the manager's job. New York: McGraw-Hill.

Katz, H. C., \& Kochan, T. A. (1992). An introduction to collective bargaining and industrial relations. New York: McGraw-Hill.

Kaufman, H. (1960). The forest ranger: A study in administrative behavior. Baltimore: Johns Hopkins University Press.

Kearney, R. C., \& Carnevale, D. G. (2001). Labor relations in the public sector (3rd ed.). New York: Marcel Dekker.

Kelman, H. C. (1961). Process of opinion change. Public Opinion Quarterly, 25(1), 55-77.

Kemper, T. (1968). Reference groups, socialization and achievement. American Sociological Review, 33(1), 31-45.

Khademian, A. M. (2002). Working with culture: The way the job gets done in public programs. Washington, DC: CQ Press.

Kilman, R. H., Saxton, M. J., \& Serpa, R. (1986). Issues in understanding and changing culture. California Management Review, 28(2), 87-94.

Klaas, B. S., \& Dell'Omo, G. (1991). The determinants of disciplinary decisions: The case of employee drug use. Personnel Psychology, 44(4), 813-835.

Klingner, D. E. (1980). Public personal management: Contexts and strategies. Englewood Cliffs, NJ: Prentice Hall.

Klingner, D. E., \& Nalbandian, J. (2003). Public personnel management: contexts and strategies (4th ed.). Englewood Cliffs, NJ: Prentice Hall.

Kunda, G. (1992). Engineering culture: Control and commitment in a high-tech corporation. Philadelphia: Temple University Press.

Louis, M. R. (1980). Surprise and sense making: What newcomers experience in entering unfamiliar organizational settings. Administrative Science Quarterly, 25(2), 226-251.

Martin, J. (1992). Cultures in organizations: Three perspectives. New York: Oxford University Press.

Martin, J. (2002). Organizational culture: Mapping the terrain. Thousand Oaks, CA: Sage.

Martin, J. F., Hatch, M. J., \& Sitkin, S. B. (1983). The uniqueness paradox in organizational stories. Administrative Science Quarterly, 28(3), 438-453.

Merton, R. K. (1957). Social theory and social structure. Glencoe, IL: Free Press.

Morgan, G., Frost, P. J., \& Pondy, L. R. (1983). Organizationalsymbolism. Greenwich, CT: JAI. 
Nalbandian, J. (1981). Performance appraisal: If only people were not involved. Public Administration Review, 41(3), 392-396.

Organ, D. W. (1987). The applied psychology of work behavior: A book of readings. Plano, TX: Business Publications.

Ott, J. S. (1989). The organizational culture perspective. Chicago: Dorsey.

Pagan, J. (1998). Discipline and first line supervisors: An ethnographic approach to the study of how supervisors handle employee discipline. Unpublished doctoral dissertation, State University of New York at Albany.

Pagan, J., \& Franklin, A. L. (2003). Understanding variation in the practice of employee discipline. Review of Public Personnel Administration, 23(1), 16-25.

Podsakoff, P. M. (1982). Determinants of a supervisor's use of rewards and punishment: A literature review and suggestions for further research. Organizational Behavior and Human Performance, 29, 58-83.

Riccucci, N. (1995). Unsung heroes: Federal execucrats making a difference. Washington, DC: Georgetown University Press.

Rivas, R. F. (1991). Dismissing problem employees. In R. L. Lewis \& J. A. Yarkey (Eds.), Skills for effective human services management (pp. 186-203). Washington, DC: NASW.

Robbins, S. P. (1994). Management. Englewood Cliffs, NJ: Prentice Hall.

Robisch, T. G. (1996). The reluctance of federal managers to utilize formal procedures for poorly performing employees. Review of Public Personnel Administration, 16(2), 73-85.

Rosen, B., \& Jerdee, T. H. (1974). Factors influencing disciplinary judgments. Journal of Applied Psychology, 59(3), 327-331.

Rosenbloom, D. H., \& Shafritz, J. M. (1985). Essentials of labor relations. Reston, VA: Reston Publishing.

Sackmann, S. A. (1991). Uncovering culture in organizations. Journal of Applied Behavioral Science, 27(3), 295-317.

Schein, E. H. (1968). Organizational socialization and the profession of management. Industrial Management Review, 9(2), 1-16.

Schein, E. H. (1985). Organizational culture and leadership. San Francisco: Jossey-Bass.

Schein, E. H. (1992). Organizational culture and leadership (2nd ed.). San Francisco: Jossey-Bass.

Seidman, H., \& Gilmour, R. (1986). Politics, position, and power: From the positive to the regulatory state (4th ed.). New York: Oxford University Press.

Selznick, P. (1948). Foundations of the theory of organization. American Sociological Review, 13(1), 25-35.

Senge, P. M. (1990). The fifth discipline: The art and practice of learning organization. New York: Doubleday.

Shafritz, J. M., Riccucci, N. M., Rosenbloom, D. H., \& Hyde, A. C. (1992). Personnel management in government: Politics and process. New York: Marcel Dekker.

Smircich, L. (1983). Concepts of culture and organizational analysis. Administrative Science Quarterly, 28(3), 339-358.

Turner, B. A. (1971). Exploring the industrial subculture. New York: Herder and Herder.

U.S. Government Accountability Office. (1978). A management concern: How to deal with the nonproductive federal employee (FPCD-78-71). Washington, DC: Author.

U.S. Government Accountability Office. (1989). Poor performance: How they are identified and dealt with in the Social Security Administration (GAO/GGD-89-28). Washington, DC: Author. 
U.S. Government Accountability Office. (1990). Performance management: How well is the government dealing with poor performers? (GAO/GGD-91-7). Washington, DC: Author.

U.S. Merit Systems Protection Board. (1992). Federal first-line supervisors: How good are they? Washington, DC: Author.

U.S. Navy Personnel Research and Development Center. (1984). The first-line supervisor: Literature review (MPRDC TR 84-18). San Diego, CA: Author.

Van Blijswijk, J. A. M., Van Breukelen, R. C. J., Franklin, A. L., Raadschelders, J. C. N., \& Slump, P. (2004). Beyond ethical codes: The management of integrity. The case of the Netherlands tax and customs administration. Public Administration Review, 64(4), 718727.

Van Maanen, J. (1976). Breaking in: Socialization to work. In R. Dubin (Ed.), Handbook of work, organization, and society (pp. 67-130). Chicago: Rand McNally.

Van Maanen, J. (1984). Doing new things in old ways: The chains of socialization. In J. L. Bess (Ed.), College and university organization (pp. 211-245). New York: New York University Press.

Van Maanen, J., \& Barley, S. R. (1984). Occupational communities: Culture and control in organizations. Research in Organizational Behavior, 6, 287-365.

Wanous, J. P. (1980). Organizational entry: Recruitment, selection and socialization of newcomers. Reading, MA: Addison-Wesley.

Werther, W. B., \& Davis, K. (1993). Human resources and personnel management. New York: McGraw-Hill.

Wheeler, H. N. (1976). Punishment theory and industrial discipline. Industrial Relations, 15(2), 235-243.

AIMEE L. FRANKLIN is an associate professor and graduate program director at the University of Oklahoma. Her research and teaching focuses on improving public management, with areas of interest in strategic planning, budgeting, evaluation, performance measurement, and ethics.

JAVIER F. PAGAN is an associate professor at the University of Puerto Rico in San Juan. He teaches courses in management, human resources, and organizational behavior. His research focuses on labor-management relations and human resource practices in public and private organizations. 